\title{
Evolution of crop yields in different tillage and cropping systems over two decades in southern Brazil
}

\author{
Julio Cezar Franchini, Henrique Debiasi*, Alvadi Antonio Balbinot Junior, Brenda Cristye Tonon, \\ José Renato Bouças Farias, Maria Cristina Neves de Oliveira, Eleno Torres
}

Embrapa Soja, PO Box 231, 86001-970 Londrina, PR, Brazil

\section{A R T I C L E I N F O}

\section{Article history:}

Received 23 April 2012

Received in revised form 3 September 2012

Accepted 5 September 2012

\section{Keywords:}

No-tillage system

Soil chiseling

Crop rotation

Glycine max

Triticum aestivum

Zea mays

\begin{abstract}
A B S T R A C T
In the last three decades, the no-tillage system (NT) has provided environmental and economic advantages for farming in southern Brazil, especially when associated with crop rotation. The objective of this study was to evaluate the effects of different tillage and cropping systems on the grain yields of soybean, maize and wheat, in a 23-year experiment established on an Oxisol in the southern region of Brazil. The experiment was carried out in randomized block experimental design with four replications. The treatments consisted of three tillage systems [NT, NT with chiseling every three years (NTC), and conventional tillage (CT)] and two cropping systems [an annual crop sequence with wheat in the winter and soybean in the summer, designated as crop succession (CS), and a 4-year crop rotation with the following species in winter-summer, respectively: white lupine-maize; black oat-soybean; wheat-soybean; and wheat-soybean (CR)]. Soybean yields were correlated to the water requirement satisfaction index (WRSI) estimated for the soybean reproductive period. With few exceptions, the NT showed higher soybean yields in relation to CT from the 7th year of the experiment onwards, especially under crop rotation and in growing seasons with lower water availability expressed by lower WRSI values. The percentage of NT soybean yield advantage over CT increased consistently over the time, and this increase was greater in CR than in CS, reaching on average $23 \%$. The yields of wheat and maize were not influenced by the tillage systems, but the wheat yields were increased by crop rotation. In the most of the growing seasons, the soil chiseling, at every three years, did not increase significantly the yields of soybean, maize and wheat. Crop rotation and NT, allowed high and stable crop yields, especially under water-stress conditions. Results indicate the need of minimizing soil disturbance and diversifying cropping system for sustainable grain production in southern Brazil.
\end{abstract}

(c) 2012 Elsevier B.V. All rights reserved.

\section{Introduction}

The sustainable production of food, fiber and bioenergy depends on tillage and cropping systems that provide high yields and, at the same time, preserve soil, water and biodiversity. The importance of continuous use of soil-conservation tillage methods, such as the no-tillage (NT), is widely recognized for the sustainability of farming systems, particularly in tropical and subtropical regions. Currently, the NT is used on more than 100 million hectares worldwide, and in Brazil, the area under NT already exceeds 25.5 million hectares (FEBRAPDP, 2011). The use of NT by farmers is mainly based on reducing fuel and agricultural machinery costs, reduction in the need of manpower, and reduction of soil erosion (Lal, 2007). Depending on environmental conditions, however, the NT can provide other benefits, as compared to conventional

\footnotetext{
* Corresponding author. Tel.: +55 4333716233.

E-mail address: debiasi@cnpso.embrapa.br (H. Debiasi).
}

tillage (CT) system, such as: better conservation of water in the soil (Alvarez and Steinbach, 2009; Putte et al., 2010; Jin et al., 2011); increase in the organic carbon contents (Bhattacharyya et al., 2009; Babujia et al., 2010); increase the microbial biomass in topsoil (Babujia et al., 2010); decrease the maximum daily soil temperature in tropical regions (Derpsch et al., 1986); and increase soil biodiversity (Adl et al., 2005). In addition, the NT reduces the time required between rainfall and the sowing procedure, thus allowing for the sowing of crops at the proper time.

Conversely, the lack of soil tillage may increase topsoil compaction into levels in which the growth of roots is limited, especially on clayey soils and/or in soils with low organic matter content (Secco et al., 2009). In southern Brazil, many farmers are performing the chiseling of soils, at regular intervals, to minimize soil compaction. However, the increase in soil bulk density and penetration resistance in the topsoil under the NT, even after periods of over a decade, have not reduced growth of roots and yield of most crops (Cavalieri et al., 2009; Lima et al., 2010). 
Changes in the physical, chemical, and biological soil properties, resulting from cropping and tillage systems carried out for long-term periods, may affect crop yields over time. In the literature, most studies correlating crop yields with tillage and cropping systems, are fairly recent, conducted in a period of less than two decades (Secco et al., 2009; Alvarez and Steinbach, 2009; Cavalieri et al., 2009; Lima et al., 2010; Putte et al., 2010; Jin et al., 2011). In some cases, the yield results are divergent, as consequence of effects of tillage and cropping systems and depend on several factors such as: soil properties, climate, crop species, cultivars, and crop management. Therefore, it is very important to carry out longterm field experiments by using the main cropping systems that are suitable for each region.

With the hypothesis that reduction of soil disturbance associated to crop rotation, increases the yield of crops over time, especially under water-stress conditions; the objective of this study was to evaluate the grain yields of soybeans, maize and wheat carried out in three tillage systems associated with two cropping systems, over a 23-years period under the southern Brazil climate conditions.

\section{Materials and methods}

\subsection{Field area and experimental design}

The field experiment was initiated in the summer of the 1988/1989 crop season, at the Embrapa Soybean experimental station, located in municipality of Londrina (latitude $23^{\circ} 11^{\prime} \mathrm{S}$; longitude $51^{\circ} 11^{\prime} \mathrm{W}$; and $620 \mathrm{~m}$ altitude), State of Paraná, southern Brazil. The climate in the area, according to Köppen climate classification, is humid subtropical (Cfa), with annual mean temperature of $21^{\circ} \mathrm{C}$, and mean maximum temperature of $28.5^{\circ} \mathrm{C}$, in February; and mean minimum temperatures of $13.3^{\circ} \mathrm{C}$, in July. The mean annual precipitation is $1651 \mathrm{~mm}$, with mean of $217 \mathrm{~mm}$, in January (the wettest month); and $60 \mathrm{~mm}$, in August (the driest month). The experiment was installed on an Oxisol (Eutroferric Red Latosol, in the Brazilian classification; or Rhodic Eutrudox, in the USA classification) with

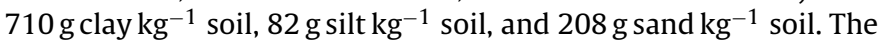
mean slope of the experimental area is $0.03 \mathrm{~m} \mathrm{~m}^{-1}$. Some chemical and physical properties of soil, evaluated at the 21 th year after installing the experiment, and performed according to the methodologies described in Babujia et al. (2010), are shown in Table 1.

Before the experiment, the area had been cultivated with coffee (Coffea arabica L.) for approximately 40 years, and the entire area had received similar management and inputs. A randomized block experimental design with four replications was used. The treatments consisted of three tillage systems [(1) no-tillage: NT, sowing directly performed through the residues of the previous crop, by opening only a narrow furrow in the sowing row; (2) no-tillage with chiseling at every three years in the winter: NTC, by means of a chisel plow equipped with five shanks, without subsequent
Table 2

Fertilization used for soybean, wheat and maize over 23 growing seasons.

\begin{tabular}{lccc}
\hline \multirow{2}{*}{ Crop } & Fertilization $^{\mathrm{a}}$ & & \\
\cline { 2 - 4 } & $\mathrm{N}\left(\mathrm{Kg} \mathrm{ha}^{-1}\right)$ & $\mathrm{P}_{2} \mathrm{O}_{5}\left(\mathrm{Kg} \mathrm{ha}^{-1}\right)$ & $\mathrm{K}_{2} \mathrm{O}\left(\mathrm{Kg} \mathrm{ha}^{-1}\right)$ \\
\hline Soybean & b,c,d & $34.0-60.0$ & $22.5-60.0$ \\
Wheat & 0.0 & $45.0-70.0$ & $24.0-40.5$ \\
Maize & $12.8-20.0$ & $28.0-75.0$ & $34.0-60.0$ \\
\hline
\end{tabular}

${ }^{a} \mathrm{~N}, \mathrm{P}_{2} \mathrm{O}_{5}$ and $\mathrm{K}_{2} \mathrm{O}$ were applied as urea, triple superphosphate and potassium chloride, respectively.

b The soybean seeds were inoculated with Bradyrhizobium elkanii and B.japonicum every growing season.

c After the 10th growing season, $20 \mathrm{~g} \mathrm{ha}^{-1}$ of molybdenum as sodium molybdate and $2 \mathrm{~g} \mathrm{ha}^{-1}$ of cobalt (cobalt chloride) were applied to the soybean seeds.

d The soybeans were not fertilized in 1998/1999 and 2000/2001.

harrowing, working at a mean depth of $0.25 \mathrm{~m}$; and (3) conventional tillage: CT, performed with disc plowing, at a mean depth of $0.20 \mathrm{~m}$, followed by a harrowing, at a working depth of $0.08 \mathrm{~m}$, preceding the summer crops, and preceding winter crops, a harrowing with a heavy harrow, at a mean depth of $0.15 \mathrm{~m}$, followed by a harrowing with a light harrow, at a working depth of $0.08 \mathrm{~m}$ ], and two crop systems [(1) wheat (Triticum aestivum L.) in the winter and soybean (Glycine max (L.) Merr) in the summer; a procedure that was repeated at each year, and designated as crop succession (CS); and (2) a 4-year crop rotation (CR), with the following species in winter-summer: white lupine (Lupinus albus L.) - maize (Zea mays L.); black oats (Avena strigosa Schreb.) - soybean; wheat - soybean; wheat -soybean]. The 6th crop rotation cycle will be ended in the 2012/2013 crop season. Each plot had the measures of $7.5 \mathrm{~m}$ in width $\times 30.0 \mathrm{~m}$ in length, thus totaling $225 \mathrm{~m}^{2}$.

Every three years, an average of $2 \mathrm{Mg} \mathrm{ha}^{-1}$ of lime was applied to the soil surface to reach a saturation of bases of $60 \%$ and to increase the $\mathrm{pH}$ in water to approximately 5.5. At each year, all plots received the same amount of fertilizers, based on soil analysis as well as on the specific recommendations for each crop (Table 2). The fertilizers $\left(\mathrm{N}, \mathrm{P}_{2} \mathrm{O}_{5}\right.$, and $\left.\mathrm{K}_{2} \mathrm{O}\right)$ were simultaneously applied $0.05 \mathrm{~m}$ below and at the side of the seeds, during the sowing procedure. For the wheat and maize, the $\mathrm{N}$ was not applied as topdressing fertilization. To the cover crops (black oats and white lupine), fertilizer was not applied.

The plots cultivated with wheat and the winter cover crops (white lupine, or black oats) were sown in the month of April in all agricultural years, since the beginning of the experiment. The wheat cultivars used were: BR 23 (1989-1994), BRS 18 (1995, 1997-2000), Ocepar 16 (1996), BRS 193 (2001 and 2002) and BRS 208 (2003-2010).

The soybean was sown in November of every crop season, and the cultivars used were: Paraná (1988/1989-1993/1994), BR 37 (1994/1995-1996/1997 and 1998/1999), Embrapa 48 (1997/1998 and 1999/2000), BRS 133 (2000/2001 and 2001/2002), BRS 156 (2002/2003 and 2003/2004), BRS 184 (2004/2005, 2008/2009 and 2009/2010) and BRS 232 (2005/2006-2007/2008).

Table 1

Soil chemical and physical properties ${ }^{\mathrm{a}}(0-0.2 \mathrm{~m})$ evaluated at the 21st year of the experiment (April/2010).

\begin{tabular}{|c|c|c|c|c|c|c|c|c|c|}
\hline \multicolumn{2}{|c|}{ Treatment $^{\mathrm{b}}$} & \multirow{2}{*}{$\frac{C\left(\mathrm{~g} \mathrm{dm}^{-3}\right)}{19.5}$} & \multirow{2}{*}{$\begin{array}{l}\mathrm{P}\left(\mathrm{mg} \mathrm{dm}^{-3}\right) \\
23.20\end{array}$} & \multirow{2}{*}{$\begin{array}{l}\mathrm{pH} \mathrm{CaCl} \\
5.22\end{array}$} & \multirow{2}{*}{$\begin{array}{l}\mathrm{K}^{+}\left(\mathrm{cmol}_{\mathrm{c}} \mathrm{dm}^{-3}\right) \\
0.37\end{array}$} & \multirow{2}{*}{$\begin{array}{l}\mathrm{Ca}^{2+}\left(\mathrm{cmol}_{\mathrm{c}} \mathrm{dm}^{-3}\right) \\
3.37\end{array}$} & \multirow{2}{*}{$\begin{array}{l}\mathrm{Mg}^{2+}\left(\mathrm{cmol}_{\mathrm{c}} \mathrm{dm}^{-3}\right) \\
1.50\end{array}$} & \multirow{2}{*}{$\begin{array}{l}\mathrm{CEC}^{\mathrm{C}}\left(\mathrm{cmol}_{\mathrm{C}} \mathrm{dm}^{-3}\right) \\
9.35\end{array}$} & \multirow{2}{*}{$\begin{array}{l}\mathrm{BD}^{\mathrm{d}}\left(\mathrm{Mg} \mathrm{m}^{-3}\right) \\
1.26\end{array}$} \\
\hline NT & $\mathrm{CR}$ & & & & & & & & \\
\hline & CS & 18.3 & 18.61 & 5.07 & 0.36 & 3.16 & 1.36 & 9.29 & 1.31 \\
\hline \multirow[t]{2}{*}{ NTC } & $\mathrm{CR}$ & 19.4 & 26.98 & 5.20 & 0.58 & 3.99 & 1.61 & 10.23 & 1.28 \\
\hline & CS & 17.7 & 24.26 & 5.10 & 0.49 & 3.27 & 1.60 & 10.54 & 1.27 \\
\hline \multirow[t]{2}{*}{$\mathrm{CT}$} & CR & 16.3 & 10.05 & 4.82 & 0.32 & 2.61 & 1.21 & 9.79 & 1.19 \\
\hline & CS & 17.4 & 12.53 & 5.19 & 0.43 & 3.31 & 1.50 & 10.72 & 1.29 \\
\hline
\end{tabular}

a Means of four replicates.

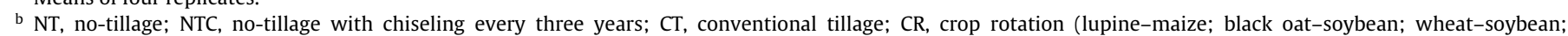
wheat-soybean); CS, crop succession (wheat-soybean).

c Cations exchange capacity $(\mathrm{CEC})=\mathrm{K}+\mathrm{Ca}+\mathrm{Mg}+$ total acidity at $\mathrm{pH} 7.0(\mathrm{H}+\mathrm{Al})$.

d Soil bulk density (BD). 
The maize was also sown in November in all agricultural years, throughout the experiment. The maize hybrids used were: $P$ 3230 (1990/1991 and 1993/1994), BRS 3123 (1997/1998), P 3041 (2001/2002), P $30 F 33$ (2005/2006) and BRS 1030 (2009/2010). The sowing, the crop management, and the control of weeds, pests, and diseases followed the technical recommendations for the cultivation of soybeans, maize and wheat and were the same for all treatments.

In the NT system, the vegetation present in the area prior to the sowing of the crops was desiccated with the herbicide glyphosate (at dosage of $720 \mathrm{~g}$ a.i. ha $\left.{ }^{-1}\right)$ mixed with mineral oil $\left(0.5 \mathrm{~L} \mathrm{ha}^{-1}\right)$.

\subsection{Grain yield}

The soybean, wheat, and maize grain yields were evaluated during the 23 years of the experiment by the mechanical harvest $25 \mathrm{~m}$ of eight, twenty or four central rows within each plot of each crop, respectively. The seeds were then cleaned and weighed; and the values obtained were corrected to $13 \%$ moisture content.

\subsection{Water requirement satisfaction index (WRSI) of the soybean culture}

The WRSI refers to the ratio between the actual crop evapotranspiration (ETr) and the maximum crop evapotranspiration (ETm). When the crop water requirements is fully met, the WRSI is equal to $1(\mathrm{ETr}=\mathrm{ETm})$. When $\mathrm{ETr}<\mathrm{ETm}(0<\mathrm{WRSI}<1)$, the crop water requirement are not being fully met, and below a given value of WRSI, the yield may be limited by water stress. In this study, the WRSI was computed only for the reproductive soybean period (stages R1-R6), which is the most critical for grain yield determination.

The ETr and ETm values were determined, for each soybean growing season, by using the BIPZON model for simulation of the crop water balance (Forest, 1984). This model uses data input as variables for: the climate (the daily rainfall and the ten-day mean potential evapotranspiration); the culture [crop coefficients $\left(K_{\mathrm{c}}\right)$ and extent of each phenological stage]; and the soil (available water capacity). The $K_{\mathrm{c}}$ coefficients, adjusted by Farias et al. (2001), were used. The available water capacity of soil was estimated in $75 \mathrm{~mm}$ (considering $0.125 \mathrm{~m}^{3} \mathrm{~m}^{-3}$ of soil available water content and a soybean root system with $0.6 \mathrm{~m}$ of effective depth). Soybean yields were correlated with the WRSI separately for each treatment.

\subsection{Statistical analysis}

Data were analyzed by the SAS system, designed for PC statistical packages (SAS Institute, 2001), using PROC GLM program (Cochran and Cox, 1957). After determining homogeneity of variance, independence and normality of residues, and the non-additivity of model, the ANOVA was performed separately for each harvest season (Burr and Foster, 1972; Shapiro and Wilk, 1965; Tukey, 1949). A combined statistical analysis considering jointly all the growing seasons was also performed. When the ANOVA resulted in a significant $P$ value $(P<0.05)$, the Tukey test was used for multiple comparisons of treatment means, at $5 \%$ probability (SAS Institute, 2001). The relationship between the WRSI and soybean yields was determined by regression analysis. The same procedure was used to correlate difference of soybean yields among the tillage systems and experiment conduction period.

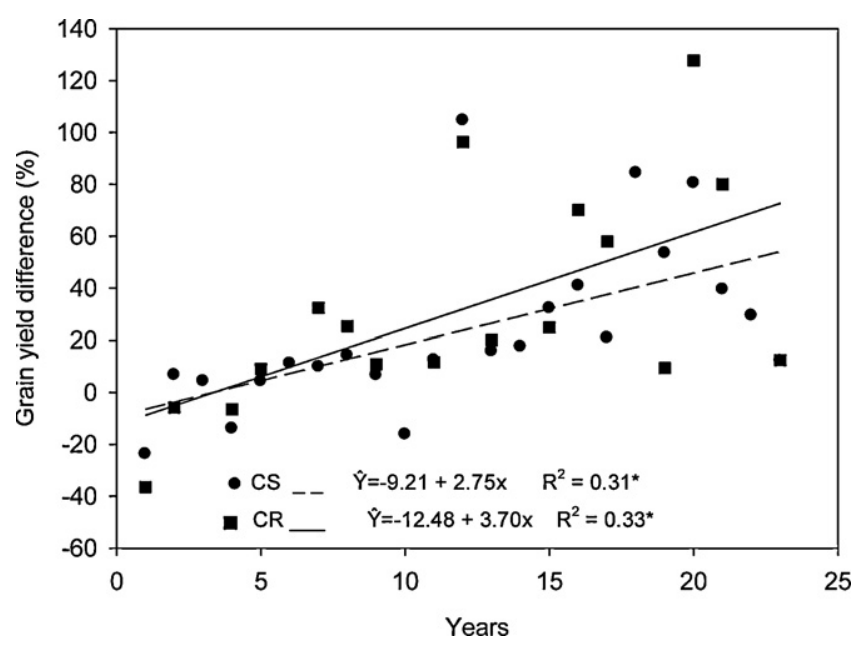

Fig. 1. Percentages of no tillage (NT) soybean grain yield increase/decrease relative to conventional tillage (CT) under crop succession (CS) and crop rotation (CR) in a 23-year experiment. * Statistically significant model $(P<0.05, F$ test $)$.

\section{Results}

\subsection{Soybean}

The interactions among the factors: growing season; tillage system; and cropping system, were statistically significant for soybean yields $(P<0.05)$. On average, the NT and NTC have provided yields substantially higher as compared to the CT (Table 3 ), but the differences varied with growing season. In the first six growing seasons, the soybean yields were usually similar among the different tillage systems (Table 3). From the 7th (1994/1995) growing season until the 23rd (2010/2011) growing season, the soybean yields were usually higher in the NTC and NT in relation to the CT (Table 3 ). During this second period, soybean yields were 32\% lower in CT than in NT and NTC. Considering the 23-years experimental period, however, the soybean yields were similar under both NT and NTC systems, except in the 1999/2000 growing season when in the CR, the NT < NTC, and in the 2005/2006 growing season when in the CS, the NT $>$ NTC (Table 3). Moreover, the soybean yields were usually similar under the CR and CS systems (Table 3), but crop rotation increased soybean yields in the NT, only in the first growing season after the maize cultivation (1991/1992, 1994/1995, and 2002/2003).

The difference on soybean yield between the systems NT and CT linearly increased over the 23 years of the experiment (Fig. 1). A similar pattern was observed for the differences between the systems NTC and CT (Fig. 2). Although the soybean yield was only slightly influenced by the cropping systems (Table 3 ), the slopes of the linear equations for CR were greater as compared to CS (Figs. 1 and 2), indicating that the annual rate of yield increase in the NT and NTC, as compared to CT, was higher in system of CR than in CS. The difference in soybean yield between the NT and CT has annually increased in approximately $3.70 \%$ and $2.75 \%$, respectively, for the CR and CS. In addition, the annual increase in the difference between NTC and CT was 3.48\% in the CR and $2.17 \%$ in the CS. Furthermore, in the first four years, the yield gap between the soil conservation systems and the $\mathrm{CT}$ was close to zero. After this period, the difference has had a trend to increase, reaching more than $60 \%$ for CR in the 23rd year of the experiment, based on the fitted regression model.

The yields of soybean have increased with the increase in the water availability for the crop, which was expressed by the WRSI values, independently of tillage or cropping systems (Fig. 3). The variation of the soybean yields with the WRSI was similar when 
Table 3

Soybean grain yields in three tillage systems ( $C T$, conventional tillage; NT, no-tillage; NTC, no-tillage with chiseling every three years) and two cropping systems (CS, crop succession; $\mathrm{CR}$, crop rotation) over 23 growing seasons. The data in parentheses refer to the water requirement satisfaction index (WRSI), calculated for the soybean reproductive phase (R1-R6 stage).

\begin{tabular}{|c|c|c|c|}
\hline $\begin{array}{l}\text { Cropping } \\
\text { systems }\end{array}$ & $\mathrm{CT}\left(\mathrm{kg} \mathrm{ha}^{-1}\right)$ & NT $\left(\mathrm{kg} \mathrm{ha}^{-1}\right)$ & NTC $\left(\mathrm{kg} \mathrm{ha}^{-1}\right)$ \\
\hline & \multicolumn{3}{|c|}{$1988 / 1989($ WRSI = 0.83) } \\
\hline CS & $1609 \mathrm{Aa}^{\mathrm{a}}$ & $1227 \mathrm{Aa}$ & $1318 \mathrm{Aa}$ \\
\hline \multirow[t]{2}{*}{$\mathrm{CR}$} & $1686 \mathrm{Aa}$ & $1072 \mathrm{Ba}$ & $1248 \mathrm{Ba}$ \\
\hline & \multicolumn{3}{|c|}{$1989 / 1990($ WRSI = 0.72) } \\
\hline CS & $2081 \mathrm{Aa}$ & $2081 \mathrm{Aa}$ & $2127 \mathrm{Aa}$ \\
\hline \multirow[t]{2}{*}{ CR } & $2132 \mathrm{Aa}$ & $2009 \mathrm{Aa}$ & $2052 \mathrm{Aa}$ \\
\hline & \multicolumn{3}{|c|}{$1990 / 1991(\mathrm{WRSI}=0.58)$} \\
\hline CS & $1872 \mathrm{~A}$ & $1954 \mathrm{~A}$ & 1929 A \\
\hline \multirow[t]{2}{*}{ CR } & - & - & - \\
\hline & \multicolumn{3}{|c|}{$1991 / 1992($ WRSI = 0.35) } \\
\hline CS & $2512 \mathrm{Aa}$ & $2163 \mathrm{ABb}$ & $2018 \mathrm{Bb}$ \\
\hline \multirow[t]{2}{*}{ CR } & $2634 \mathrm{Aa}$ & $2462 \mathrm{Aa}$ & $2532 \mathrm{Aa}$ \\
\hline & \multicolumn{3}{|c|}{$1992 / 1993(\mathrm{WRSI}=0.83)$} \\
\hline CS & $2853 \mathrm{Aa}$ & $2977 \mathrm{Aa}$ & $2767 \mathrm{Aa}$ \\
\hline \multirow[t]{2}{*}{ CR } & $2684 \mathrm{Aa}$ & $2928 \mathrm{Aa}$ & $2838 \mathrm{Aa}$ \\
\hline & \multicolumn{3}{|c|}{$1993 / 1994(\mathrm{WRSI}=0.73)$} \\
\hline CS & $2824 \mathrm{~A}$ & $3139 \mathrm{~A}$ & $3007 \mathrm{~A}$ \\
\hline \multirow[t]{2}{*}{ CR } & - & - & - \\
\hline & & 94/1995 (WRS & \\
\hline CS & $3019 \mathrm{Ba}$ & $3319 \mathrm{ABb}$ & $3490 \mathrm{Ab}$ \\
\hline CR & $2925 \mathrm{Ba}$ & $3874 \mathrm{Aa}$ & $4200 \mathrm{Aa}$ \\
\hline & & 95/1996 (WRS & \\
\hline CS & $3433 \mathrm{Ba}$ & 3922 Aa & $3640 \mathrm{ABa}$ \\
\hline CR & $3018 \mathrm{Bb}$ & $3782 \mathrm{Aa}$ & $3870 \mathrm{Aa}$ \\
\hline & & 96/1997 (WRS & \\
\hline CS & $3183 \mathrm{Ab}$ & 3396 Аа & $3331 \mathrm{Aa}$ \\
\hline CR & $3427 \mathrm{Aa}$ & $3389 \mathrm{Aa}$ & $3366 \mathrm{Aa}$ \\
\hline & & 97/1998 (WRS & \\
\hline CS & 2569 A & $2153 \mathrm{~A}$ & 2456 A \\
\hline CR & - & - & - \\
\hline & & 98/1999 (WRS & \\
\hline CS & $3429 \mathrm{Ba}$ & $3856 \mathrm{Aa}$ & $3775 \mathrm{ABa}$ \\
\hline CR & $3189 \mathrm{Bb}$ & $3560 \mathrm{Ab}$ & $3733 \mathrm{Aa}$ \\
\hline & & 99/2000 (WRS & \\
\hline CS & $1663 \mathrm{Ba}$ & $3403 \mathrm{Aa}$ & $3360 \mathrm{Ab}$ \\
\hline CR & $1624 \mathrm{Ca}$ & $3188 \mathrm{Ba}$ & $3794 \mathrm{Aa}$ \\
\hline & & 00/2001 (WRS & \\
\hline CS & $3143 \mathrm{Ba}$ & $3640 \mathrm{Aa}$ & $3594 \mathrm{Aa}$ \\
\hline CR & $2811 \mathrm{Bb}$ & $3375 \mathrm{Aa}$ & $3562 \mathrm{Aa}$ \\
\hline & & 01/2002 (WRS & \\
\hline CS & 2815 B & $3310 \mathrm{~A}$ & $3130 \mathrm{AB}$ \\
\hline CR & - & - & - \\
\hline & & 02/2003 (WRS & \\
\hline CS & $2518 \mathrm{Bb}$ & $3330 \mathrm{Ab}$ & $3216 \mathrm{Ab}$ \\
\hline CR & $3021 \mathrm{Ba}$ & $3770 \mathrm{Aa}$ & 3615 Aa \\
\hline & & 03/2004 (WRS & \\
\hline CS & $1947 \mathrm{Ba}$ & $2743 \mathrm{Aa}$ & $2478 \mathrm{Aa}$ \\
\hline CR & $1565 \mathrm{Bb}$ & $2662 \mathrm{Aa}$ & 2646 Aa \\
\hline & & 04/2005 (WRS & \\
\hline CS & $2125 \mathrm{Ba}$ & 2569 Аа & $2555 \mathrm{Aa}$ \\
\hline CR & $1471 \mathrm{Bb}$ & $2650 \mathrm{Aa}$ & $2747 \mathrm{Aa}$ \\
\hline & & 05/2006 (WRS & \\
\hline CS & $1815 \mathrm{C}$ & $3346 \mathrm{~A}$ & 2672 B \\
\hline CR & - & - & - \\
\hline & & 06/2007 (WRS & \\
\hline CS & $2336 \mathrm{Bb}$ & $3585 \mathrm{Aa}$ & $3512 \mathrm{Aa}$ \\
\hline CR & $3152 \mathrm{Aa}$ & $3448 \mathrm{Aa}$ & $3269 \mathrm{Ab}$ \\
\hline & & 07/2008 (WRS & \\
\hline CS & $2000 \mathrm{Ba}$ & $3610 \mathrm{Aa}$ & $3835 \mathrm{Aa}$ \\
\hline CR & $1502 \mathrm{Bb}$ & $3421 \mathrm{Aa}$ & $3541 \mathrm{Ab}$ \\
\hline & & 08/2009 (WRS & \\
\hline CS & $2871 \mathrm{Ba}$ & $4005 \mathrm{Aa}$ & $3963 \mathrm{Aa}$ \\
\hline CR & $2130 \mathrm{Bb}$ & $3835 \mathrm{Aa}$ & 3799 Аа \\
\hline & & 09/2010 (WRS & \\
\hline CS & 2592 B & $3355 \mathrm{~A}$ & $3091 \mathrm{~A}$ \\
\hline CR & - & - & - \\
\hline & & 10/2011 (WRS & \\
\hline CS & $2875 \mathrm{Ba}$ & $3225 \mathrm{Aa}$ & $3320 \mathrm{Aa}$ \\
\hline CR & $2767 \mathrm{Aa}$ & $3112 \mathrm{Aa}$ & $3032 \mathrm{Ab}$ \\
\hline
\end{tabular}

Table 3 (Continued)

\begin{tabular}{|c|c|c|c|}
\hline Cropping systems & $\mathrm{CT}\left(\mathrm{kg} \mathrm{ha}^{-1}\right)$ & NT $\left(\mathrm{kg} \mathrm{ha}^{-1}\right)$ & NTC $\left(\mathrm{kg} \mathrm{ha}^{-1}\right)$ \\
\hline \multicolumn{4}{|l|}{ Means } \\
\hline $\mathrm{CT}$ & 2496 & & \\
\hline NT & 3071 & & \\
\hline NTC & 3061 & & \\
\hline CR & 2904 & & \\
\hline CS & 2855 & & \\
\hline
\end{tabular}

a Means followed by equal letters, lowercase in the columns and uppercase in the rows, do not differ by the Tukey test $(P<0.05)$.

compared to the NTC and NT, either within CR system (Fig. 3A) or the CS system (Fig. 3B). Although the relationship between soybean yield and the values for WRSI in the CT was linear, data have shown that soybean yields were limited by water stress when the WRSI values were lower than 0.80 , either for the CR system (Fig. 3A) or the CS system (Fig. 3B). Nevertheless, the soybean yields, in the NT and NTC began to decrease only when the values of WRSI have dropped to figures below 0.70 , thus demonstrating that soil conservation systems are efficient strategies to increase drought tolerance as compared to the CT system. Furthermore, the differences on soybean yield, between the soil conservation systems and the $\mathrm{CT}$, have increased when the WRSI values decreased for both the CR (Fig. 3A) and CS systems (Fig. 3B).

\subsection{Wheat}

The interaction between the factors: growing seasons $\times$ tillage systems, was statistically significant for the wheat yield $(P<0.05)$. In CS system, the wheat yield was significantly affected by tillage systems, but these effects were not clear and have had large variations among growing seasons (Table 4).

From another stand point, in CR system the CT did not result in higher wheat yield, in relation to the other tillage systems, in any of the growing seasons, thus reinforcing the importance of crop rotation, mainly in soil conservation tillage systems for wheat yield stability.

Similarly to the results obtained for soybean, soil chiseling, at regular intervals, have had only small effects on wheat yields. Thus, the NTC increased the wheat yields in relation to NT only in three out of the 22 growing seasons in CS system (1997/1998, 2001/2002 and 2002/2003) (Table 4). Similar results were obtained for the CR system, where wheat yield was increased by the NTC system,

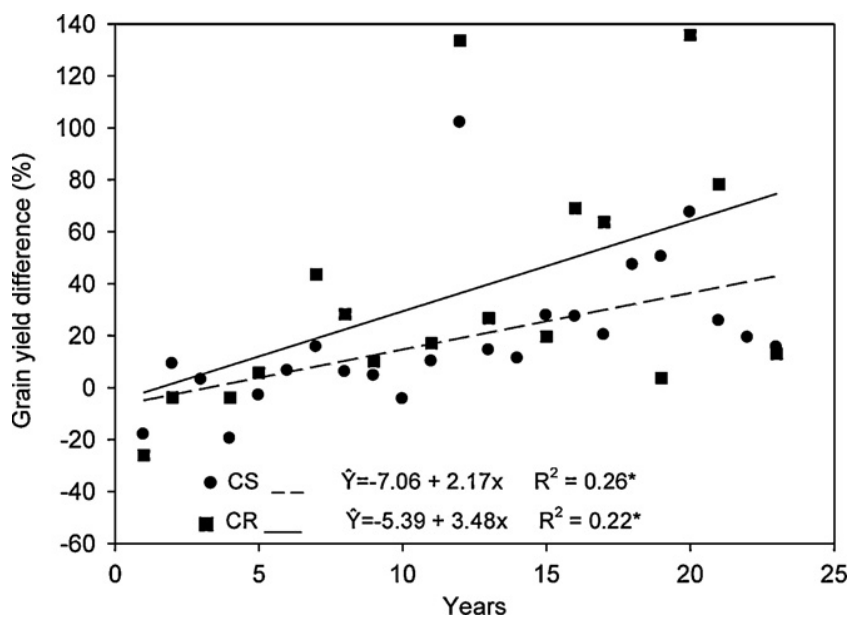

Fig. 2. Percentages of no tillage with chiseling every three years (NTC) soybean grain yield increase/decrease relative to conventional tillage (CT) under crop succession $(\mathrm{CS})$ and crop rotation (CR) in a 23-year experiment. * Statistically significant model $(P<0.05, F$ test $)$. 

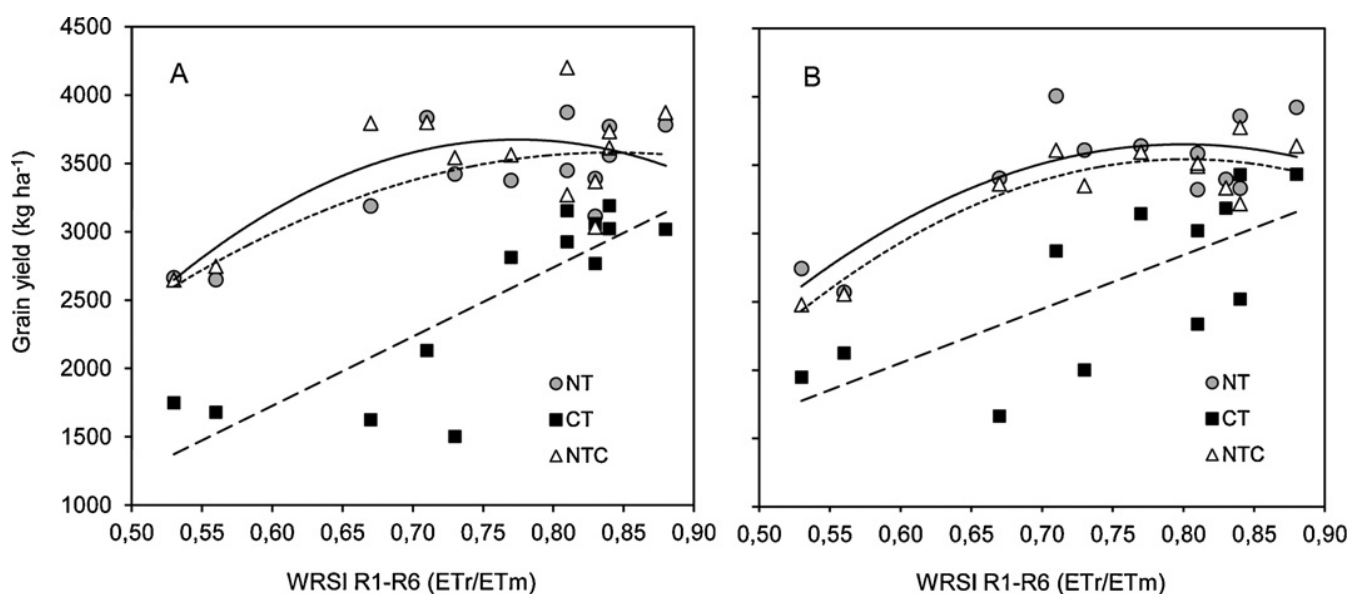

$\begin{array}{lll}-(N T) & \hat{Y}=-3575+16996 x-10093 x^{2} & R^{2}=0.65^{\star *} \\ ---(C T) & \hat{Y}=-1307+5058 x & R^{2}=0.71^{\star \star} \\ - \text { (NTC) } \hat{Y}=-6634+26626 x-17194 x^{2} & R^{2}=0.51^{\star *}\end{array}$

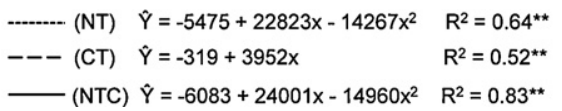

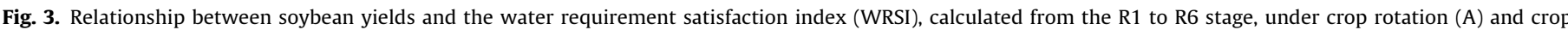

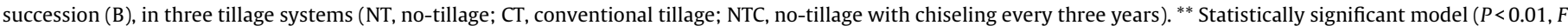
test).

in relation to NT, only in two growing seasons (1999/2000 and 2008/2009) (Table 5).

The interaction between tillage systems, as well as growing seasons $\times$ cropping systems was not statistically significant $(P<0.05)$. However, the wheat yield during nine growing seasons, and under the three tillage systems, has had a mean $6.8 \%$ higher in the CR system $\left(2495 \mathrm{~kg} \mathrm{ha}^{-1}\right)$ than in the CS system $\left(2334 \mathrm{~kg} \mathrm{ha}^{-1}\right)(P<0.05)$.

\subsection{Maize}

For the maize yield, the interaction between tillage systems $\times$ growing seasons was statistically significant $(P<0.05)$. The yield of maize was larger in the CT, as compared to the NT, in the

Table 4

Wheat grain yields in three tillage systems (CT, conventional tillage; NT, notillage; NTC, no-tillage with chiseling every three years) under crop succession (CS, wheat-soybean) over 23 growing seasons.

\begin{tabular}{lrrr}
\hline Growing seasons & CT $\left(\mathrm{kg} \mathrm{ha}^{-1}\right)$ & NT $\left(\mathrm{kgha}^{-1}\right)$ & NTC $\left(\mathrm{kgha}^{-1}\right)$ \\
\hline $1989 / 1990$ & $613 \mathrm{a}^{\mathrm{a}}$ & $653 \mathrm{a}$ & $774 \mathrm{a}$ \\
$1990 / 1991$ & $2500 \mathrm{a}$ & $2237 \mathrm{a}$ & $2147 \mathrm{a}$ \\
$1991 / 1992$ & $906 \mathrm{a}$ & $1059 \mathrm{a}$ & $937 \mathrm{a}$ \\
$1992 / 1993$ & - & - & - \\
$1993 / 1994$ & $3044 \mathrm{a}$ & $2328 \mathrm{~b}$ & $2214 \mathrm{~b}$ \\
$1994 / 1995$ & - & - & - \\
$1995 / 1996$ & $2593 \mathrm{a}$ & $2302 \mathrm{a}$ & $2308 \mathrm{a}$ \\
$1996 / 1997$ & $1327 \mathrm{~b}$ & $1852 \mathrm{a}$ & $1935 \mathrm{a}$ \\
$1997 / 1998$ & $3224 \mathrm{a}$ & $2881 \mathrm{~b}$ & $3222 \mathrm{a}$ \\
$1998 / 1999$ & $2638 \mathrm{a}$ & $2425 \mathrm{ab}$ & $2178 \mathrm{~b}$ \\
$1999 / 2000$ & $3060 \mathrm{a}$ & $2735 \mathrm{a}$ & $2972 \mathrm{a}$ \\
$2000 / 2001$ & $2219 \mathrm{a}$ & $2120 \mathrm{a}$ & $2013 \mathrm{a}$ \\
$2001 / 2002$ & $3366 \mathrm{a}$ & $2746 \mathrm{~b}$ & $3250 \mathrm{a}$ \\
$2002 / 2003$ & $982 \mathrm{~b}$ & $1021 \mathrm{~b}$ & $1282 \mathrm{a}$ \\
$2003 / 2004$ & $3132 \mathrm{a}$ & $3211 \mathrm{a}$ & $3149 \mathrm{a}$ \\
$2004 / 2005$ & $2802 \mathrm{a}$ & $2776 \mathrm{a}$ & $2617 \mathrm{a}$ \\
$2005 / 2006$ & $1981 \mathrm{~b}$ & $2513 \mathrm{a}$ & $2374 \mathrm{a}$ \\
$2006 / 2007$ & - & - & - \\
$2007 / 2008$ & $1564 \mathrm{~b}$ & $2132 \mathrm{a}$ & $1792 \mathrm{ab}$ \\
$2008 / 2009$ & $3042 \mathrm{a}$ & $2972 \mathrm{a}$ & $3194 \mathrm{a}$ \\
$2009 / 2010$ & $1651 \mathrm{a}$ & $1794 \mathrm{a}$ & $1657 \mathrm{a}$ \\
$2010 / 2011$ & $2816 \mathrm{a}$ & $3048 \mathrm{a}$ & $3023 \mathrm{a}$ \\
Means & 2287 & 2253 & 2265 \\
\hline $\mathrm{a}$ & 2253 & $\mathrm{a}$ &
\end{tabular}

a Means followed by equal letters in the rows do not differ by the Tukey test $(P<0.05)$.
Table 5

Wheat grain yields in three tillage systems (CT, conventional tillage; NT, notillage; NTC, no-tillage with chiseling every three years) under crop rotation (CR, lupine-maize; black oat-soybean; wheat-soybean; wheat-soybean) over nine growing seasons.

\begin{tabular}{lccc}
\hline Growing seasons & CT $\left(\mathrm{kg} \mathrm{ha}^{-1}\right)$ & NT $\left(\mathrm{kg} \mathrm{ha}^{-1}\right)$ & NTC $\left(\mathrm{kg} \mathrm{ha}^{-1}\right)$ \\
\hline $1991 / 1992$ & $961 \mathrm{a}^{\mathrm{a}}$ & $1034 \mathrm{a}$ & $1049 \mathrm{a}$ \\
$1992 / 1993$ & - & - & - \\
$1995 / 1996$ & $2611 \mathrm{a}$ & $2543 \mathrm{a}$ & $2603 \mathrm{a}$ \\
$1996 / 1997$ & $1305 \mathrm{~b}$ & $1970 \mathrm{a}$ & $2078 \mathrm{a}$ \\
$1999 / 2000$ & $3060 \mathrm{ab}$ & $2870 \mathrm{~b}$ & $3149 \mathrm{a}$ \\
$2000 / 2001$ & $2227 \mathrm{a}$ & $2176 \mathrm{a}$ & $2196 \mathrm{a}$ \\
$2003 / 2004$ & $3086 \mathrm{a}$ & $3267 \mathrm{a}$ & $3255 \mathrm{a}$ \\
$2004 / 2005$ & $2856 \mathrm{a}$ & $2877 \mathrm{a}$ & $2824 \mathrm{a}$ \\
$2007 / 2008$ & $1717 \mathrm{~b}$ & $2047 \mathrm{a}$ & $2032 \mathrm{a}$ \\
$2008 / 2009$ & $3075 \mathrm{ab}$ & $3045 \mathrm{~b}$ & $3282 \mathrm{a}$ \\
Means & 2322 & 2425 & 2496 \\
\hline
\end{tabular}

a Means followed by equal letters in the rows do not differ by the Tukey test $(P<0.05)$

first growing season (1990/1991) and with the NT and NTC systems in the second growing season (1993/1994), but the differences from the 7 th year on (3rd crop of maize) were usually small (Table 6). In addition, the maize yield in the NTC were higher in relation to the NT only in the 2001/2002 growing season, thus showing that soil chiseling, performed at every three years, is not an effective practice to increase the maize yield.

Table 6

Maize grain yields in three tillage systems (CT, conventional tillage; NT, no-tillage; NTC, no-tillage with chiseling every three years) under crop rotation (CR) over six growing seasons.

\begin{tabular}{lccc}
\hline Growing seasons & CT $\left(\mathrm{kg} \mathrm{ha}^{-1}\right)$ & NT $\left(\mathrm{kg} \mathrm{ha}^{-1}\right)$ & NTC $\left(\mathrm{kg} \mathrm{ha}^{-1}\right)$ \\
\hline $1990 / 1991$ & $4380 \mathrm{a}^{\mathrm{a}}$ & $3138 \mathrm{~b}$ & $4055 \mathrm{ab}$ \\
$1993 / 1994$ & $7666 \mathrm{a}$ & $5195 \mathrm{~b}$ & $5064 \mathrm{~b}$ \\
$1997 / 1998$ & $6220 \mathrm{a}$ & $6526 \mathrm{a}$ & $5863 \mathrm{a}$ \\
$2001 / 2002$ & $8624 \mathrm{~b}$ & $8420 \mathrm{~b}$ & $9112 \mathrm{a}$ \\
$2005 / 2006$ & $5845 \mathrm{a}$ & $4474 \mathrm{~b}$ & $5547 \mathrm{ab}$ \\
$2009 / 2010$ & $7005 \mathrm{a}$ & $6753 \mathrm{a}$ & $6799 \mathrm{a}$ \\
Means & 6623 & 5751 & 6073
\end{tabular}

${ }^{a}$ Means followed by equal letters in the rows do not differ by the Tukey test $(P<0.05)$. 


\section{Discussion}

In the last decade, several studies have shown that the yield of crops is influenced by the tillage systems, but the results have been contradictory. Some studies have reported that the yield of crops is increased under the NT as compared to the CT system (McGregor et al., 2006; Fontoura and Bayer, 2008; Jin et al., 2011). However, the inverse $(\mathrm{CT}>\mathrm{NT})$ has also already been reported by other authors (Putte et al., 2010; Messiga et al., 2012). Furthermore, no differences in crop yields between the systems CT and NT have also been observed (Alvarez and Steinbach, 2009; Lima et al., 2010; Mupangwa et al., 2012). Tillage effects on crop yields depends on several factors, such as: climate, soil properties, crops and their interaction with the rotation crop, cultivars, management practices, and water availability during the growing season (Alvarez and Steinbach, 2009), leading to discrepancies, which are usually observed in the results. Thereby, studies about the evolution of the crop yields, under different tillage and cropping systems, and based on long-term field experiments can contribute to clarify the impacts of soil management on the yield of crops.

According to McGregor et al. (2006), the stabilization phase of the NT in their study lasted four years, during which the soybean yield was lower in the NT than in the CT system. In the same study, these authors found that the soybean yields in the NT, from the 5th to the 14 th year, has had a mean $62 \%$ higher than in the CT system, characterizing the maturity phase of the NT system. Fontoura and Bayer (2008) have also reported that the stabilization phase of the NT considering the soybean yield, lasted four years in southern Brazil. In our study, the soybean yield in the NT and NTC systems were equal to or lower than in the CT system, during the first six years, thus suggesting that the stabilization phase of the soil tillage conservation systems had already reached its end. From the 7th year on, the soybean yield was consistently higher in the NT and NTC as compared to the CT system, consequently indicating that the soil conservation systems had finally reached the maturity phase.

The stabilization phase in the NT and NTC systems can be considered as a period needed for that the increase of the soil organic carbon take place, to such an extent in which the soil quality is considerably improved as compared to the CT system. In the same experiment of our study, Babujia et al. (2010) observed that the NT system resulted in a gain of $16 \mathrm{MgCha}^{-1}$ in the $0.0-0.6 \mathrm{~m}$ layer, over a 20 -years period, when compared to the CT system. Increases in the carbon stocks in the NT, in relation to CT system, were also reported in studies carried out by other authors (Franchini et al., 2007; Barreto et al., 2009; Boddey et al., 2010). Organic carbon accumulation in the soil is known to produce several benefits for several processes and attributes of soil, which are correlated to crop growth, such as: the formation and stabilization of soil aggregates (Bhattacharyya et al., 2009), reduction on soil bulk density (Jarecki et al., 2005), higher soil water retention (Rawls et al., 2003), increases in the cations exchange capacity and nutrient availability (Sá et al., 2009), reduction on the activity of toxic mineral elements, such as the aluminum (Franchini et al., 2001), and increases in the amounts, diversity, and activity of the soil biota (Pereira et al., 2007).

The higher soybean yields, observed in the NT and NTC as compared to the CT system may also be attributed to the differences in the efficiency of biological nitrogen fixation (BNF) among treatments. Data obtained in an experiment carried out by Pereira et al. (2007) have shown that the contribution of BNF for the requirements of $\mathrm{N}$ for the soybean was higher in the NT, as compared to the CT system. Such result may be ascribed to a greater efficiency of the nodules on the roots of soybean plants grown in the NT system, mainly due to the more suitable environmental conditions of the soil (temperature and moisture content) to the rhizobia.
According to Zotarelli et al. (2012), the NT has increased the N biologically fixed by rhizobia in the soybean in $31 \mathrm{~kg} \mathrm{ha}^{-1} \mathrm{year}^{-1}$, comparatively to the CT system. In addition, the reduction of soil erosion in the tillage systems used for soil conservation (Engel et al., 2009) may partially explain the greater yields of soybean observed in the NT and NTC systems.

McGregor et al. (2006) reported that the greatest differences between the NT and CT systems on the soybean yields occurred during dry years and Jin et al. (2011) have observed a similar pattern for maize and wheat. In both studies, yields were correlated with the rainfall during the growing season and in this study, the WRSI was a satisfactory indicator of water availability for plants. The difference in the soybean yields between the tillage systems for soil conservation and the CT system was increased when the values for WRSI diminished, for both the CR and CS systems, indicating that NT and NTC were effective practices for reducing soybean yield losses related to water stress by drought.

The tolerance to drought was higher in tillage systems for soil conservation and was associated with the reduced evaporation of the soil water due to mulching (Monzon et al., 2012; Mupangwa et al., 2012). Greater water storage and its availability to plants was a consequence of improved soil structure (Alvarez and Steinbach, 2009; Jin et al., 2011). In terms of structure, the reduction on tillage intensity leads to preservation of the soil biopores. Biopores are known for being means highly effective for the water easy movement through the soil, once they are structures long, continuous, and stable (Oades, 1993), enabling the vertical upward flow of water from subsoil to the topsoil layer. Moreover, in soil conservation systems, the best soil physical quality associated to soil cover by plant residues, increases water storage in the soil by greatly reducing water losses by runoff (Engel et al., 2009).

Results herein obtained suggest that the soil structure is the main factor responsible for higher soybean yields in the NT and NTC systems during the second period assessed (from 1994/1995 to 2010/2011), once the soil cover by crop residues were also present in the first period (from 1988/1989 to 1993/1994). Furthermore, the values for WRSI were estimated during the soybean reproductive period (stages R1-R6), when the soil surface was completely covered by the canopy of plants; this way allowing occurrence of water losses from the soil mainly through leaf transpiration.

Yields of wheat and maize were lower in the system NT, than in $\mathrm{CT}$ system, when the $\mathrm{N}$ was a limiting nutrient what has already been frequently reported as such (Alvarez and Steinbach, 2009; Zotarelli et al., 2012; Kihara et al., 2012). As the immobilization of $\mathrm{N}$ is usually higher in the NT system (Hungria et al., 2009), and the CT system accelerates mineralization of $\mathrm{N}$ in the organic matter from soil and plant residues (Ferreira et al., 2009), lower amounts of $\mathrm{N}-\mathrm{NO}_{3}$ have been found in the NT than in the CT system (Alvarez and Steinbach, 2009).

In general, the maize yield has had a better response than wheat in relation to availability of $\mathrm{N}$-mineral in the soil (Schmitt and Edwards, 1981). In this study, the wheat yield was similar when the soil conservation tillage systems were compared with the CT system. Conversely, maize yield was greater in the CT system than in the NT system during stabilization phase, probably due to immobilization of $\mathrm{N}$ and the low amounts of $\mathrm{N}$-fertilizer applied. However, the differences decreased over the time, probably as a consequence of the progressive reduction of N stocks in the soil in the CT system; caused by the increased oxidation of the soil organic matter by intensive tillage. Likewise, data obtained in this experiment have shown that after 20 years, the soil $\mathrm{N}$ stocks in the CT system were reduced by $16 \%$, in depths of $0.0-0.6 \mathrm{~m}$, when compared to the NT system (Babujia et al., 2010). Furthermore, when the stocks of $\mathrm{N}$ in the soil were increased over time, within the NT system, the amount of $\mathrm{N}$ mineralized was equal, or has even exceeded, the quantity of $\mathrm{N}$ immobilized, over the long term period (Franchini et al., 2000, 
2007). In contrast, under the Brazilian environmental conditions the soybean yield was not restricted by $\mathrm{N}$ availability in the soil, once about $93 \%$ of $\mathrm{N}$, required by the soybean crop, was supplied by the BNF (Pereira et al., 2007).

In Brazil, a compacted soil layer, at the $0.1-0.2 \mathrm{~m}$ depth has been observed in some agricultural areas cultivated under the NT system (Secco et al., 2009). The cultural practice of soil chiseling, in the NT system was identified as an efficient way to break this layer of compacted soil; thus increasing the yield of crops (Klein and Camara, 2007). In this study, however, it was found that the yields of soybean, wheat and maize were only slightly influenced by the soil chiseling performed at every three years. In the CR system, the NTC surpassed the soybean yield obtained in the NT system only in one of the 23 growing seasons assessed (1999/2000). Within the CS system, statistically significant differences in productivity between the NT and NTC were found only in one growing season (2005/2006), and in this case, the chiseling reduced the soybean yield. In addition, the soil chiseling has not increased the soybean tolerance to drought, as compared to the NT, as clearly shown when soybean yields were correlated to the WRSI. Over a 22-years period, the wheat yield was increased by the chiseling practice only in three years in the CS system and in two years in the CR system. Likewise, the maize yield was higher in the NTC than in the NT, only in one of the six growing seasons evaluated. In this experiment, Franchini et al. (2011) found that the compaction level within the NT system, at 0.1-0.2 m depth, after 21 years was not limiting for root growth; what can explain the small effects of the soil chiseling cultural practice on yield of crops. Nevertheless, when the soil compaction level was not limiting for root growth, the chiseling of soil, at regular time intervals in the NT system has not enabled improvements on yield; even under drought conditions.

Crop rotation has been widely recommended as an effective cultural practice for increasing soil quality and crop yields in southern Brazil. Despite the emphasis given to the matter, studies on effects of crop rotation on yield are still scarce and results achieved have been contradictory (Silva et al., 2010; Zotarelli et al., 2012). In the present study, the increments on soybean yield observed in the NT and NTC in relation to the CT system were higher in the CR than in the CS system; emphasizing the importance of a diversified cropping system to improve crop yields. Besides, the higher the organic carbon content in the soil, the higher will be the growth of plants and the addition of plant biomass provided by the CR system (Franchini et al., 2007; Zotarelli et al., 2012); thus contributing to enhance the microbial biomass in the soil (Silva et al., 2010) as well as its diversity (Pereira et al., 2007). This contribution allows for a higher efficiency in several key microbial processes for maximizing soybean yield such as: BNF, recycling of nutrients, and suppression of disease-causing agents (Hungria et al., 2009). Similarly, wheat yields were higher in the CR system than in the CS system, regardless the tillage system used as cultural practice. The positive effects of the CR system on wheat yields can be attributed mainly to reduction of incidence and severity of some diseases (Santos and Reis, 2001), such as: root rot caused by Gaeumannomyces graminis (Sacc.) and Bipolaris sorokiniana (Sacc.), and leaf spot caused by Drechslera tritici-repentis (Died.),Stagonospora nodorum (Berk.) and B. sorokiniana (Sacc.).

\section{Conclusions}

The evolution of grain yield of wheat, maize, and especially soybean, over time demonstrates the existence of a stabilization phase of the no-tillage system, which lasts approximately six years, when the crop productivity in this system tends to be less than or equal to the conventional tillage system.
After the 7th year, the no-tillage system, with or without chiseling at every three years, provides higher soybean yield when compared to the conventional tillage system, particularly in growing seasons with low water availability or carried out in the crop rotation system.

The yield of wheat and maize are usually similar among tillage systems.

In most growing seasons, crop yield is not increased by soil chiseling under the no-tillage system.

Soil conservation and crop rotation systems are needed to minimize soil disturbance and diversify the cropping system for a sustainable grain production in southern Brazil.

\section{Acknowledgement}

This paper was approved for publication by the Editorial Board of Embrapa Soja as manuscript number 03/2012. This work was partially funded by CNPq (National Council for Scientific and Technological Development, project 562453/2010-5).

\section{References}

Adl, S.M., Coleman, D.C., Read, F., 2005. Slow recovery of soil biodiversity in sandy loam soils of Georgia after 25 years of no-tillage management. Agric. Ecosyst. Environ. 114, 323-334.

Alvarez, R., Steinbach, H.S., 2009. A review of the effects of tillage systems on some soil physical properties, water content, nitrate availability and crops yield in the Argentine Pampas. Soil Till. Res. 104, 1-15.

Babujia, L.C., Hungria, M., Franchini, J.C., Brookes, P.C., 2010. Microbial biomass and activity at various soil depths in a Brazilian oxisol after two decades of no-tillage and conventional tillage. Soil Biol. Biochem. 42, 2174-2181.

Barreto, R.C., Madari, B.E., Maddock, J.E.L., Machado, P.L.O.A., Torres, E., Franchini, J.C., Costa, A.R., 2009. The impact of soil management on aggregation, carbon stabilization and carbon loss as $\mathrm{CO}_{2}$ in the surface layer of a Rhodic Ferralsol in Southern Brazil. Agric. Ecosyst. Environ. 132, 243-251.

Bhattacharyya, R., Prakash, V., Kundu, S., Srivastva, A.K., Gupta, H.S., 2009. Soil aggregation and organic matter in a sandy clay loam soil of the Indian Himalayas under different tillage and crop regimes. Agric. Ecosyst. Environ. 132, 126-134.

Boddey, R.M., Jantalia, C.P., Conceição, P.C., Zanatta, J.A., Bayer, C., Mielniczuk, J., Dieckow, J., Dos Santos, H.P., Denardin, J.E., Aita, C., Giacomini, S., Alves, B.J.R., Urquiaga, S., 2010. Carbon accumulation at depth in Ferralsols under zero-til subtropical agriculture. Global Change Biol. 16, 784-795.

Burr, I.W., Foster, L.A., 1972. A Test for Equality of Variances. University of Purdue West Lafayette, USA (26 Mimeo series, 282).

Cavalieri, K.M.V., Silva, A.P., Tormena, C.A., Leão, T.P., Dexter, A.R., Hakansson, I., 2009. Long-term effects of no-tillage on dynamic soil physical properties in a Rhodic Ferrasol in Paraná, Brazil. Soil Till. Res. 103, 158-164.

Cochran, W.G., Cox, G., 1957. Experimental Designs. John Wiley, New York, NY, USA, p. 661.

Derpsch, R., Sidiras, N., Roth, C.H., 1986. Results of studies made from 1977 to 1984 to control erosion by cover crops and no-tillage techniques in Paraná, Brazil. Soil Till. Res. 8, 253-263.

Engel, F.L., Bertol, I., Ritter, S.R., Paz González, A., Páz-Ferreiro, J., Vidal Vázquez, E., 2009. Soil erosion under simulated rainfall in relation to phenological stages of soybeans and tillage methods in Lages, SC, Brazil. Soil Till. Res. 103, 216-221.

Farias, J.R.B., Assad, E.D., Almeida, I.R., Evangelista, B.A., Lazzarotto, C., Neumaier, N., Nepomuceno, A.L., 2001. Caracterização de risco climático nas regiões produtoras de soja no Brasil (Characterization of the water deficit for Brazilian soybean producing regions). R. Bras. Agromet. 9, 415-421.

Federação Brasileira de Plantio Direto na Palha (FEBRAPDP), 2011. Available from: http://www.febrapdp.org.br (accessed 23.08.11).

Ferreira, A.O., Sá, J.C.M., Briedis, C., Figueiredo, A.G., 2009. Desempenho de genótipos de milho cultivados com diferentes quantidades de palha de aveia-preta e doses de nitrogênio (Corn genotype performance under black oat crop residues and nitrogen fertilization). Pesq. Agropec. Bras. 44, 173-179.

Fontoura, S.M.V., Bayer, C., 2008. Trinta anos do experimento de manejo de solo, Guarapuava, PR (Thirty years of soil management experimente, Guarapuava, PR), Guarapuava, FAPA, p. 55

Forest, F., 1984. Simulation du bilan hydrique des cultures pluviales. In: Présentation et utilization du logiciel BIP, Irat-Cirad, Montpellier, p. 63.

Franchini, J.C., Borkert, C.M., Ferreira, M.M., Gaudêncio, C.A., 2000. Alterações na fertilidade do solo em sistemas de rotação de culturas em semeadura direta (Soil fertility changes on no-tillage crop rotation systems). R. Bras. Ci. Solo 24 $459-467$.

Franchini, J.C., Vila, F.G., Cabrera, F., Miyazawa, M., Pavan, M.A., 2001. Rapid transformations of plant water soluble organic compounds in relation to cation mobilization in an acid soil. Plant Soil 231, 55-63. 
Franchini, J.C., Crispino, C.C., Souza, R.A., Torres, E., Hungria, M., 2007. Microbiological parameters as indicators of soil quality under various soil management and crop rotation systems in southern Brazil. Soil Till. Res. 92, 18-29.

Franchini, J.C., Costa, J.M., Debiasi, H., Torres, E., 2011. Importância da rotação de culturas para a produção agrícola sustentável no Paraná (Importance of crop rotation to sustainable agricultural production in Paraná), Embrapa Soja, Londrina/PR, Brazil, p. 52 (Documentos, 327).

Hungria, M., Franchini, J.C., Brandão-Junior, O., Kaschuk, G., Souza, R.A., 2009. Soil microbial activity and crop sustainability in a long-term experiment with three soil-tillage and two crop-rotation systems. Appl. Soil Ecol. 42, 288-296.

Jarecki, M.K., Lal, R., James, R., 2005. Crop management effects on soil carbon sequestration on selected farmers' fields in ortheastern Ohio. Soil Till. Res. 81, 265-276.

Jin, H., Hongwen, L., Rasaily, R.G., Qingjie, W., Guohua, C., Yanbo, S., Xiaodong, Q., Lijin, L., 2011. Soil properties and crop yields after 11 years of no tillage farming in wheat-maize cropping system in North China Plain. Soil Till. Res. 113, 48-54.

Kihara, J., Bationo, A., Waswa, B., Kimetu, J.M., Vanlauwe, B., Okeyo, J., Mukalama, J., Martius, C., 2012. Effect of reduced tillage and mineral fertilizer application on maize and soybean productivity. Exp. Agric. 48, 159-175.

Klein, V.A., Camara, R.K., 2007. Rendimento da soja e intervalo hídrico ótimo em Latossolo Vermelho sob plantio direto escarificado (Soybean grain yield and least limiting water range in an Oxisol under chiseled no-tillage). R. Bras. Ci. Solo 31, 221-227.

Lal, R., 2007. Constraints to adopting no-till farming in developing countries. Soil Till. Res. 94, 1-3.

Lima, C.L.R., Reinert, D.J., Reichert, J.M., Suzuki, L.E.A.S., 2010. Produtividade de culturas e resistência à penetração de Argissolo Vermelho sob diferentes manejos (Yield of crops and soil resistance to penetration of the Alfisol under different management). Pesq. Agropec. Bras. 45, 89-98.

McGregor, K.C., Cullum, R.F., Mutchler, C.K., Johnson, J.R., 2006. Long-term no-till and conventional-till soybean yields (1983-1999), MAFES, Mississippi State, USA, p. 14 (MAFES. Bulletin, 1146).

Messiga, A.J., Ziadi, N., Morel, C., Grant, C., Tremblay, G., Lamarre, G., Parent, L.-E., 2012. Long term impact of tillage practices and biennial $P$ and $N$ fertilization on maize and soybean yields and soil P status. Field Crop Res. 133, 10-22.

Monzon, J.P., Sadras, V.O., Andrade, F.H., 2012. Modelled yield and water use efficiency of maize in response to crop management and Southern Oscillation Index in a soil-climate transect in Argentina. Field Crop Res. 130, 8-18.

Mupangwa, W., Twomlow, S., Walker, S., 2012. Reduced tillage, mulching and rotational effects on maize (Zea mays L.), cowpea (Vigna unguiculata (Walp) L.) and sorghum (Sorghum bicolor L. (Moench)) yieldsunder semi-arid conditions. Field Crop Res. 132, 139-148.

Oades, J.M., 1993. The role of biology in the formation, stabilization and degradation of soil structure. Geoderma 56, 377-400.

Pereira, A.A., Hungria, M., Franchini, J.C., Kaschuk, G., Chueire, I.M.O., Campo, R.J. Torres, E., 2007. Variações qualitativas e quantitativas na microbiota do solo e na fixação biológica do nitrogênio sob diferentes manejos com soja (Qualitative and quantitative changes in soil microbiota and biological nitrogen fixation under different soybean managements). R. Bras. Ci. Solo 31, 1397-1412.

Putte, A.V., Govers, G., Diels, J., Gillijns, K., Demuzere, M., 2010. Assessing the effect of soil tillage on crop growth: a meta-regression analysis on European crop yields under conservation agriculture. Eur. J. Agron. 33, 231-241.

Rawls, W.J., Pachepsky, Y.A., Ritchie, J.C., Sobecki, T.M., Bloodworth, H., 2003. Effect of soil organic carbon on soil water retention. Geoderma 116, 61-76.

Sá, J.C.M., Cerri, C.C., Lal, R., Dick, W.A., Piccolo, M.C., Feigl, B.E., 2009. Soil organic carbon and fertility interactions affected by a tillage chronosequence in a Brazilian Oxisol. Soil Till. Res. 104, 56-64.

Santos, H.P., Reis, E.M., 2001. Rotação de culturas em plantio direto (Crop rotation under no-tillage). Embrapa Trigo, Passo Fundo/RS, Brazil, p. 212.

Institute, S.A.S., 2001. Proprietary of Software, Version 8.2, 6th ed. SAS Institute, Cary, NC, USA.

Secco, D., Reinert, D.J., Reichert, D.J., Silva, V.R., 2009. Atributos físicos e rendimento de grãos de trigo, soja e milho em dois Latossolos compactados e escarificados (Crop yield and physical attributes in two oxisols compacted and chiseled). Cienc. Rural 39, 58-64.

Shapiro, S.S., Wilk, M.B., 1965. An analysis of variance test for normality. Biometrika 52, 591-611.

Schmitt, M.R.S., Edwards, G.E., 1981. Photosynthetic capacity and nitrogen use efficiency of maize, wheat, and rice: a comparison between C3 and C4 photosynthesis. J. Exp. Bot. 32, 459-466.

Silva, A.P., Babujia, L.C., Franchini, J.C., Souza, R.A., Hungria, M., 2010. Microbial biomass under various soil- and crop-management systems in short and longterm experiments in Brazil. Field Crop Res. 119, 20-26.

Tukey, J.W., 1949. One degree of freedom for non-additivity. Biometrics 5 $232-242$

Zotarelli, L., Zatorre, N., Boddey, R.M., Urquiaga, S., Jantalia, C.P., Franchini, J.C., Alves, B.J.R., 2012. Influence of no-tillage and frequency of a green manure legume in crop rotations for balancing $\mathrm{N}$ outputs and preserving soil organic $\mathrm{C}$ stocks. Field Crop Res. 132, 185-195. 